\title{
Marxismo, prática política e deslocamento
}

\author{
Rodrigo Oliveira Fonsecal
}

Resumen: El artículo analiza críticamente, en el ámbito del materialismo histórico, la relación entre práctica política y materialidad social- histórica, con el objetivo de superar los modelos que neutralizan las fuerzas productivas y la disciplina capitalista de empresa, y que terminan sustituyendo un intelecto político-formal por un intelecto administrativo-gestor. Considerando que la práctica política ocupa un punto central en la conformación de las clases sociales, se propone aquí caracterizar esta "conformación" como vertreten, representación, agencia, y a este "punto central" en el medio a los procesos de desplazamiento y desidentificación de las formas históricas y discursivas de sujeción y ordenamiento de los cuerpos sociales. Las principales contribuciones teóricas movilizadas advienen de Michel Pêcheux, João Bernardo, Jacques Rancière y Gayatri Spivak.

Palabras-clave: marxismo; economicismo; práctica política; luchas ideológicas; clases sociales.

Resumo: $\mathrm{O}$ artigo discute criticamente, no âmbito do materialismo histórico, a relação entre prática política e materialidade sócio-histórica, visando superar os modelos que neutralizam as forças produtivas e a disciplina capitalista de empresa e que acabam substituindo um intelecto político-formal por um intelecto administrativo-gestorial. Considerando que a prática política ocupa um lugar central na conformação das classes sociais, propõe-se aqui caracterizar esta "conformação" enquanto vertreten, representação, agenciamento, e este "lugar central" em meio a processos de deslocamento e desidentificação frente às formas históricas e discursivas de assujeitamento e ordenamento dos corpos sociais. As principais contribuições teóricas mobilizadas provêm de Michel Pêcheux, João Bernardo, Jacques Rancière e Gayatri Spivak.

Palavras-chave: marxismo; economicismo; prática política; lutas ideológicas; classes sociais.

\section{Introdução}

Se os homens fazem a história, mas não como querem, ou se a história está em constante transformação através de processos que não são nem transparentes, nem já dados, nem ideais, mas sim materialmente contraditórios - comportando ao mesmo tempo

1 Mestre em História pela PUC-Rio e Doutor em Letras pela UFRGS. 
permanências e rupturas que se entrecruzam -, o mínimo que se deve "esperar" daquelas pesquisas que, pelo menos, se inspiram no materialismo histórico e, se perspicazes, lhe dão trabalho, é a elucidação de alguns elementos desse porvir, para além da vontade de se colocar a seu favor. Afinal, não é por ser porvir que trará boas novas... Como sublinhou a bióloga Ariane Leite Larentis em debate no VII Colóquio Internacional Marx e Engels², o sentido do elogio de Marx à descoberta de Darwin não reside em nenhum otimismo quanto a algum caráter progressista da evolução, mas exatamente à historicização das transformações no âmbito da vida animal, que compreende não apenas processos de adaptação, mas, igualmente, de extinção. Sendo assim, o materialismo histórico que para nós merece investimento é aquele que não autoriza futurologias e, menos ainda, alguma fé num futuro melhor, de modo a efetivamente contribuir na elucidação das possibilidades reais e das lutas que estão materialmente inscritas em nossa época de mundialização e transnacionalização do capital. Produzir a análise concreta da situação concreta, na formulação de Lenin, mas também, e fundamentalmente, "fornecer um modo de análise especialmente bem equipado para explorar o terreno no qual a ação política deverá ter lugar”, de acordo com Ellen Meiksins Wood (apud MONTENEGRO, 2012, p. 114).

É pertinente lembrar a afirmação de F. Engels (1890) de que o materialismo histórico deve nos servir de guia para os estudos, e nunca como substituto aos estudos - como já vinha ocorrendo desde pelo menos a década de 1870, através de alguns jovens entusiastas das obras de Marx, os primeiros "marxistas", aqueles de que Marx tentou se desvencilhar afirmando que não era marxista. Com esse entendimento, o de um guia para os estudos, ou ainda o de um método com "pontos de apoio para uma investigação ulterior" (ENGELS, 1895), acreditamos que o principal modo pelo qual o materialismo histórico pode nos guiar numa investigação como a pleiteada por este artigo, de processos que supostamente são apenas superestruturais, é ajudando a identificar e compreender os fatores de transição e de ruptura concretos e imanentes a uma formação social: identificar e compreender os traços de outra ordem latente que habita de modo subterrâneo ou subalterno a ordem dominante e que se manifestam a partir de eventos de caráter desestruturante, com destaque para as crises econômicas, mas também para os muitos lapsos, falhas e desvios que cotidianamente se manifestam em nossas atividades linguageiras-enunciativas, tais como:

[...] não entender ou entender errado; não "escutar" as ordens; não repetir as litanias ou repeti-las de modo errôneo, falar quando se exige silêncio; falar sua língua como uma língua estrangeira que se domina mal; mudar, desviar, alterar o sentido das palavras e das frases; tomar os enunciados ao pé da letra; deslocar as regras na sintaxe e desestruturar o léxico jogando com as palavras...

E assim começar a se despedir do sentido que reproduz o discurso da dominação, de modo a que o irrealizado advenha formando sentido do interior do sem-sentido. E através destas quebras de rituais, destas transgressões de fronteiras: [...] o momento imprevisível em que uma série heterogênea de efeitos individuais entra em ressonância e produz um acontecimento histórico, rompendo o círculo da repetição (PÊCHEUX, 1990 [1982], p. 17).

\section{Uma superestrutura cobre uma estrutura? Questões sobre o materialismo histórico.}

No final deste recorte, nos deparamos com uma lógica da processualidade histórica - comum a Foucault e Althusser - pela qual os acontecimentos são resultado de efeitos

2 Edição de 2012 do evento bianual organizado na Unicamp pelo Centro de Estudos Marxistas, CEMARX. 
individuais acumulados, imprevisíveis, inconscientes, etc. É uma ideia de causalidade estrutural tributária daquilo que na psicanálise se conceituou enquanto processo de sobredeterminação e que, no espaço do inconsciente, representam um acúmulo de sintomas em parte independentes, em parte ligados entre si, que produzem um trauma. No espaço da estrutura social, representariam um acúmulo de circunstâncias contraditórias heterogêneas, de diferentes níveis e origens, que produzem uma ruptura (INDURSKY, 1997, p. 194-195).

Divergindo deste empréstimo, entendemos que as diversas formas de resistência ideológica cotidiana nas práticas enunciativas - tais como "não escutar" as ordens, não repetir as litanias ou repeti-las de modo errôneo, tomar os enunciados ao pé da letra etc. - só produzem acontecimentos, isto é, sentido no interior do sem-sentido, se são discursivamente agenciados. Não sendo manipuláveis por um Sujeito trans-histórico oculto, errático e imprevisível, estes traços de outra ordem latente não se juntam nem vão tomar formas por si mesmos e tampouco podem ser considerados de forma harmônica e unidirecional. Assim como existem traços multiformes de coletivismo e de igualitarismo (bases fundamentais para o fim da sociedade de classes), existem também outros tantos traços de individualismo radical (em prol de um anarco-capitalismo) e de integrismos (de nacionalismos e fundamentalismos), dentre outros.

Queremos com isso dizer que não existe espontaneidade pura na história, o que faria coincidir com uma mecanicidade pura (GRAMSCI, 2002 [1929-35], p. 194). Se a sociedade não é um somatório de indivíduos, também a transformação não se configura jamais como somatória de resistências individuais e pontuais; ela é fruto da práxis dos sujeitos históricos. Do mesmo modo como uma crise não produz por si só a sua resolução, um somatório de resistências não pode ser mais do que a matéria-prima passiva à espera de um labor. E tanto no campo das leituras teleológicas e futurologistas do marxismo quanto nesse outro campo que ressalta a imprevisibilidade e um caráter aleatório dos acontecimentos, é reduzido à insignificância o papel do trabalho político de formação de novos sujeitos e relações sociais. Consideramos, pelo contrário, que é somente através da prática política e discursiva que eventos de caráter desestruturante podem ser agenciados, formando novas consciências, produzindo subjetivações, efeitos sociais de primeira grandeza.

De modo amplo, na base destas subjetivações, podemos considerar uma miríade de estruturas e de acontecimentos que são agenciados ou "perdidos" aos interesses sociais de transformação, como são também agenciados ou "perdidos" aos interesses sociais de reprodução ${ }^{3}$. Por exemplo, os efeitos produzidos pelas lutas por melhores salários e condições de trabalho sobre o aumento da produtividade nas empresas, que representam o agenciamento/recuperação daquelas lutas por parte dos capitalistas, sem que por isso tenham deixado de significar também conquistas e aprendizagem por parte dos trabalhadores envolvidos. Podemos bem ver aí de que são feitos os efeitos sociais: de estruturas e acontecimentos históricos articulados em processos, podendo ser experimentados pelos sujeitos sob diferentes aspectos - da disfunção à oportunidade, da adversidade ao corte que se sutura ou que se abre ainda mais.

"Articulados", "agenciados" ou mesmo "formatados"... para além do revezamento das formas verbais, interessa aqui circunscrever explicitamente uma objeção de nossa parte às leituras mecanicistas e economicistas do marxismo que transformam a base (ou estrutura) social de instância passiva (ou materialidade) em instância ativa (em sujeito)

3 Sem que haja dicotomia entre transformação e reprodução, o que pode ser bem percebido pela lógica do capitalismo de transformação incessante, pela qual a reprodução se faz enquanto valorização do valor, e não repetição do mesmo. 
no processo histórico. Não se faz ou não há história sem condições e coerções históricas, mas é igualmente absurdo pensar que se possa fazer ou que possa haver história somente através de suas condições materiais. Trabalhando uma metáfora que Marx usa para falar da economia política (MARX, 2008 [1859]), reconhecemos que a anatomia de um corpo diz muito das suas possibilidades de movimento, mas não pode prevê-los e menos ainda provocá-los. A determinação e o agenciamento na história devem ser considerados conjuntamente de modo a se evitar os conhecidos desvios deterministas e voluntaristas. A verdade é que a separação metodológica entre os dois grandes momentos de um modo de produção, estrutura e superestrutura social, induz a tropeços, na medida em que se fragiliza o caráter dialético da compreensão histórica iniciada por Marx ${ }^{4}$.

Nesse sentido, questionamos a separação proposta por Louis Althusser (1970) entre as funções de produção e as de reprodução do todo social, que grosso modo se sustentam numa divisão entre um dentro e um fora do local de trabalho: o despotismo fabril de um lado, demandando um aparelho repressivo, e a igualdade entre sujeitos livres, sujeitos de direitos e deveres, demandando aparelhos ideológicos. Tal divisão acaba espelhando a própria separação ideológica burguesa entre espaço privado da economia e espaço público da política (e da educação, alçada por Althusser à condição dominante nos aparelhos ideológicos do Estado). Parece-nos mais exato quebrar essa (quarta) parede do "local" de trabalho e conceber, como o fez Karl Marx em um de seus manuscritos de Paris (MARX, 1993 [1844], p. 193), que "a religião, a família, o Estado, o Direito, a moral, a ciência, a arte, etc., constituem apenas modos particulares da produção e submetem-se à sua lei geral". No entanto, não deixa de ser proveitoso tecer uma distinção pela qual a) na produção do todo social capitalista, o elemento fundamental caracteriza-se pela extorsão/exploração dos trabalhadores, que, ao mesmo tempo, proletariza as maiorias e gera acumulação de capital, constituindo globalmente os fatores elementares, os sujeitos livres do sistema, enquanto que b) na reprodução do capitalismo, o fundamental é a luta de classes, pensada na forma de um continuum de lutas, não lineares, mas em forma de ciclos (BERNARDO, 2009 [1991]), onde os sentidos de liberdade são experimentados e disputados nos mais variados espaços sociais, inclusive, e em especial, nos de extorsão.

Vale acrescentar ainda uma contribuição crítica notável de Michel Pêcheux quanto ao problema da produção/reprodução social no texto de Althusser:

A leitura que Michel Pêcheux fazia do famoso texto de Althusser era original e
marcava uma intuição teórica muito fina. Acrescentando a palavra "transformação"
na fórmula consagrada utilizada por Althusser sobre a reprodução das relações de
produção, ele tentava desmanchar as interpretações funcionalistas que o texto althus-
seriano não parava de suscitar (MALDIDIER, 2003 [1990], p. 49).

Mais adiante, no artigo, veremos que a contribuição de Pêcheux ao ponto é muito mais vasta que o acréscimo de uma palavra e o esclarecimento de que os aparelhos ideológicos de Estado são o lugar de uma batalha.

Estrutura e superestrutura não representam diferentes funções e espaços de definição dos processos históricos, com o cotidiano de uma empresa transnacional de um lado e uma

4 Tropeços dos quais Marx não deve ser isentado, pois nos seus escritos tanto a luta de classes como o desenvolvimento das forças produtivas aparecem no papel de "motor" da história. Apoiada em Engels, Plekhanov, Trotski e Stálin, até os anos 1960, essa segunda vertente era o senso comum no campo marxista, quando então, a partir do maoísmo, da Revolução Cubana e das lutas anticoloniais, a centralidade da luta de classes na compreensão da história foi recuperada. 
sessão parlamentar extraordinária de outro, ou os bancos e propriedades territoriais da igreja católica de um lado e a sua condenação do aborto de outro, ou ainda, o trabalho para se produzir telas de LCD de um lado e os produtos de entretenimento que ali aparecerão de outro. Estrutura e superestrutura são mais bem compreendidas historicamente enquanto funcionamentos e momentos inseparáveis de uma ordem social, na qual não cabe ao Estado e às suas instituições latu sensu (como o parlamento, a Igreja e a mídia corporativa) um papel secundário ou coadjuvante e, menos ainda, o de um tapume que encobriria as condições materiais de existência. Se assim fosse, se o fundamental das superestruturas fosse determinar o que não pode ou não deve ser visto e dito, com diferentes gradações, se fossem instâncias de pura negação e encobrimento, elas não aproveitariam o potencial narrativo-ideológico dos fatores sociais tendencialmente escondidos e ainda potencializariam os sentidos destes. Não é nenhuma elucubração elencar essa hipótese que aqui contestamos, já que a lógica do tapume pode ter sido dominante por muito tempo ou, ao menos, em algumas conjunturas particulares. No entanto, no atual regime de visibilidade, mesmo com toda a assimetria que o caracteriza, seria muito difícil imaginar a reprodução das relações sociais dominantes sendo operada somente na base de mecanismos de encobrimento.

Além desse papel de tapume, outra possibilidade a se aventar é a de que o Estado e suas instituições cumpram um papel positivo análogo ao de uma estufa que protege e otimiza as relações sociais dominantes. Não o desvio da atenção ou o encobrimento de certas cenas, mas o cuidado de se evitar que determinadas pragas possam se criar e proliferar num espaço. Se setorizarmos esta estufa protetora, se a subdividirmos em diferentes tarefas ou setores, podemos parodiar a conceituação proposta por Michel Pêcheux (1997 [1975], p. 160) para as formações discursivas: aquilo que determina o que pode e deve ser dito a partir de uma posição dada numa formação social, proporcionando o sentido das expressões. Pêcheux não fala aí de "formação social" e sim de "conjuntura", mas uma tal traição e paródia estruturalista de seu texto nos serve para exemplificar bem como essa lógica da estufa (que cobre, protege e otimiza relações) sucumbe num engessamento da crítica ideológica, através de um pré-texto que dissemina a cegueira para o duplo fato de que mesmo as estufas não podem ser redomas e que as pragas são mutantes. A Análise do Discurso proposta por Michel Pêcheux se desenvolveu, inclusive, sublinhando o caráter instável das fronteiras entre as formações discursivas, os efeitos de conjuntura na prática social do fazer sentido e o caráter dinâmico das lutas ideológicas.

Tendo de avançar, afirmamos em síntese que as superestruturas políticas, jurídicas e ideológicas não cobrem a base social, toda a sua materialidade, nem como tapume diversionista nem como estufa protetora. Elas fundamentalmente atuam em seu interior, ativamente, em todos os vãos das relações sociais. A relação psicanalítica que se estabelece entre fantasia imaginária e falta/incompletude real talvez possa ser explorada como analogia para a compreensão do elo superestrutura-estrutura. Como diz Slavoj Zizek (1996, p. 325), a estrutura de fantasia determina nossa atividade, nosso modo de agir na realidade. As superestruturas assim atuam. Não se trata de nenhum esfumaçamento da estrutura social ou do real da história e seu papel na determinação das práticas, mas uma recuperação da radicalidade do dizer de Marx (2008 [1859], p. 48) de que é sob formas ideológicas que os homens tomam consciência dos conflitos de seu tempo e os levam até o fim. Mas nem as ideologias devem ser pensadas apenas enquanto formas (encobrindo conteúdos), nem as tomadas de consciência são descobertas (de um objeto pré-existente), devendo ser pensadas antes enquanto tomadas de partido em meio a um conflito, posicionamentos com base em fatores históricos estruturais $\mathrm{e}(\mathrm{m})$ suas conjunturas, o modo como são imaginariamente 


\section{Conexão Letras}

preenchidas e perseguidas as faltas e os desejos constitutivos em um ordenamento social.

Por outra via, que igualmente fortalece a concepção de momentos no lugar daquela outra de espaços para a relação entre estrutura e superestrutura, pensamos que dos modos de produzir e reproduzir uma formação social, com os seus valores e os seus desvalidos, com suas formas específicas de acumulação e de desapropriação, desenham-se contornos de relações de direito que definem e estabilizam as divisões entre os modos de fazer, os modos de ser e os modos de dizer ${ }^{5}$ de uma formação social. O Estado, como principal elemento superestrutural, é assim o estado da luta de classes, um certo modo de assegurar determinadas conquistas e de suturar as feridas de uma batalha - continuando-a por outras vias. É, sob essa compreensão, uma determinada forma de fazer política, forma esta que Rancière nomeia de polícia, enquanto uma lógica ou um ordenamento

que faz que tais corpos sejam designados por seu nome para tal lugar e tal tarefa; é uma ordem do visível e do dizível que faz com que essa atividade seja visível e outra não o seja, que essa palavra seja entendida como discurso e outra como ruído. É, por exemplo, uma lei de polícia que faz tradicionalmente do lugar de trabalho um espaço privado não regido pelos modos do ver e dizer próprios do que se chama o espaço público, onde o ter parcela do trabalhador é estritamente definido pela remuneração de seu trabalho. A polícia não é tanto uma "disciplinarização" dos corpos quanto uma regra de seu aparecer, uma configuração das ocupações e das propriedades dos espaços em que essas ocupações são distribuídas (RANCIÉRE, 1996, p. 42. Grifos do autor).

Tais divisões e designações aparecem teorizadas por Michel Pêcheux no campo da discursividade, são os universos logicamente estabilizados, com uma infinidade de coisas-a-saber, reservas de conhecimento acumulado que geram laços de dependência social e configuram uma rede de dispositivos e recursos protetores contra ameaças de toda espécie à reprodução social: da epidemia de dengue à queda do PIB, do terremoto e tsunami à greve dos rodoviários. Diante de todas estas urgências e ameaças à felicidade humana, os sujeitos pragmáticos (cada um de nós no papel de gestores cotidianos da vida) demandamos homogeneidade lógica, um mundo semanticamente estabilizado e a atualização de fronteiras que nos auxiliam nas infinitas tomadas de decisão do dia a dia. "O Estado e as instituições funcionam o mais frequentemente - pelo menos em nossa sociedade - como pólos privilegiados de resposta a essa necessidade ou a essa demanda" (PÊCHEUX, 1997 [1983], p. 34). E, se for justa a asserção, temos uma vez mais a insuficiência prática de se desviar o foco e se contentar com a clássica alusão à determinação em última instância... que apenas traveste o que já se supunha.

\section{Marxismo Ciência-Estado versus Marxismo conhecimento e luta política contra a exploração}

O sentido do marxismo enquanto interpretação materialista da história e prática política transformadora precisa ser resgatado, de modo a se poder isolar e identificar melhor os seus diversos desvirtuamentos - com destaque para a sua transformação numa Ciência-Estado (ciência régia para PÊCHEUX, 1997 [1983], ou ciência total para NETTO, 1984). Ellen Meiksins Wood identifica em algumas obras de Marx a predominância de uma racionalidade econômica e determinista, que ela chama de interpretação burguesa do

5 Trazendo aqui o modo como Jacques Rancière (em $O$ desentendimento: política e filosofia. São Paulo: Editora $34,1996)$ talvez viesse a formular a presente questão. 
devir histórico do capitalismo, contra a qual ela defende uma segunda narrativa, presente (pelo menos os seus fundamentos) n'O Capital, em que Marx evidenciaria “o caráter aberto do devir histórico, submetido às injunções das lutas sociais e políticas entre as classes" (MONTENEGRO, 2012, p. 113). João Bernardo diverge não do teor, mas daquela localização na obra marxiana e dos termos de referência a uma interpretação burguesa em seu interior. N'O Capital, Marx teria entronizado a disciplina capitalista de empresa, contrastando a organização fabril com uma suposta desorganização e arbitrariedade do mercado e servindo-se daquela organização (do seu desenvolvimento planificado, não da sua ruptura) como base de passagem ao modo de produção futuro, ao socialismo (BERNARDO, 2009 [1991], p. 408-413).

A despeito da consideração dos Grundrisse de que "o ser humano é, no sentido mais literal, um animal político, não apenas um animal social, mas também um animal que somente pode isolar-se em sociedade" (MARX, 2011 [1857], p. 40), não se deve esquecer o postulado pelo Manifesto Comunista de que "toda luta de classes é uma luta política", mas "desaparecidos os antagonismos de classe no curso do desenvolvimento e sendo concentrada toda a produção propriamente falando na mão dos indivíduos associados, o poder político perderá seu caráter político" (MARX \& ENGELS, 1998 [1848], p. 28). Quase trinta anos depois, Engels falará da substituição do governo sobre as pessoas pela direção dos processos produtivos e administração das coisas. Não ocorria a ele que qualquer relação entre sujeitos e coisas é fundamentalmente uma relação entre sujeitos. Foram drásticos os efeitos desse intelecto administrativo-gestorial sobre o socialismo soviético, em que "a ordem social, pretensamente desembaraçada dos efeitos da luta de classes, converte-se em uma ordem natural, na qual não há lugar para contradições: quando muito 'dificuldades de organização"” (PÊCHEUX, 1990 [1982], p. 14). "Enquanto, de um lado, considerava-se que estas [as classes] haviam desaparecido, de outro, afirmava-se que as relações de produção correspondiam perfeitamente às forças produtivas, e que qualquer contradição eventual deveria desaparecer em tempo útil, graças à 'sociedade socialista"” (BETTELHEIM, 1976, p. 33).

Por aí, vemos bem o caráter absolutamente estratégico da consideração teórica da prática política no interior do marxismo como forma de combate às suas posições e versões tecnicistas, gestoras e burguesas. Não é difícil supor que, se formos capazes de superar a nossa pré-história - estes muitos séculos de luta de classes -, outras lutas aparecerão, outras subjetividades e incompletudes animarão o todo social. Por isso, subordinar/restringir a política e sua necessidade somente às posições que tocam as assimetrias nos modos de produzir e apropriar também é uma forma de postergar um problema. Se toda luta de classes é uma luta política, nem toda luta política é luta de classes.

Em um texto de crítica radical ao politicismo, Karl Marx (2011 [1844]) é explícito ao categorizar a política enquanto esfera limitada e limitadora da ação e da compreensão do social, considerando o intelecto político sinônimo de pensamento burguês, mistificador do poder da vontade e adversário das perspectivas políticas e teóricas que se pautam pela totalidade, vaticinando que, juntamente ao Estado, a própria política deveria ser abolida.

O Estado jamais encontrará no "Estado e na organização da sociedade" o fundamento dos males sociais [...]. Onde há partidos políticos, cada um encontra o fundamento de qualquer mal no fato de que não ele, mas o seu partido adversário acha-se no leme do Estado. Até os políticos radicais e revolucionários já não procuram o fundamento do mal na essência do Estado, mas numa determinada forma de Estado, no lugar da qual eles querem colocar uma outra forma de Estado. (MARX, 2011 [1844], p. 43). 
Se a formulação nos ajuda a pensar na movimentação dos partidos (inclusive a dos revolucionários), não faz o mesmo em relação à compreensão do Estado. Afinal, de que modo um Estado deriva de uma formação social e atua na sua reprodução?

N'A Ideologia Alemã , a relação entre sociedade e Estado se dá da seguinte forma: a partir de uma conexão materialista dos homens - a única que faz com que seja legítimo pensar em uma história geral da humanidade -, desenvolvem-se interesses coletivos referentes à dependência recíproca dos indivíduos entre os quais o trabalho social está dividido, interesses estes que na história assumiram uma forma autônoma sobre esta base real dos laços sociais existentes: a forma de Estado, pela qual, sem que se questione a manutenção da divisão social do trabalho, as lutas reais entre as classes assumem formas ilusórias (MARX \& ENGELS, 1993 [1846], p. 47-48).

Jacques Rancière resiste a essa categorização, a qual ele classifica de meta-política: uma sintomatologia que implica conceber a falsidade como a verdade própria do político. A distância entre a verdade social e a falsidade política apareceria de modo intransponível na tradição marxista; a política seria aquilo que ela esconde: a luta de classes, o movimento real da sociedade (RANCIÈRE, 1996, p. 89). A distância entre o cidadão rousseauniano e o homem hobbesiano, entre a (ilusão da) soberania cidadã e a (verdade da) guerra civil passa, assim, do estatuto de condicionante de uma realização/transposição - a emancipação humana como ultrapassagem dos limites da cidadania política, segundo o jovem Marx $^{6}-$ para a figura de uma denúncia, na qual o próprio social, o movimento real da sociedade, é desenhado como algo destituído de política, sendo "sempre redutível, em última instância, à simples não-verdade da política" (ibidem, p. 90). É por isso que "Marx só concebia a possibilidade de consolidação de uma forma social pós-capitalista, se essa estivesse desembaraçada do revestimento político" (BRITO, 2005, p. 13).

Os marxistas ainda hoje se revezam entre a politização da sociedade, do cotidiano, da economia, por um lado, e o esforço pela superação da política como parte da superação da sociabilidade burguesa. Provavelmente temos um equívoco no cruzamento dessas duas referências à política, como ainda se tem tantas vezes nas referências ingênuas que são feitas à sociedade civil e seus poderes enquanto uma exterioridade em relação ao Estado.

\section{Classes sociais, representação e prática discursiva}

No entanto, um ponto sensível e central para se pensar a prática política no marxismo é o das classes sociais, muitas vezes naturalizado, seja para dizer que ele já está dado, ainda que na condição de uma pura objetividade social desconhecida, seja para dele apressadamente se despedir, adeus. É ele objeto de conceituação interrompida no final inconcluso d'O Capital, mas se encontra desenvolvido ao longo da produção teórica marxiana: o proletariado aparece como herói revolucionário nos primeiros escritos, classe sem interesses e conteúdos próprios (Macunaíma?), pura negação da sociabilidade burguesa, enquanto que nas obras da maturidade ele é o conjunto dos homens subsumidos à exploração capitalista, dentre outras determinações. Quando Marx considera os elementos objetivos e diferenciais que conformam as classes em seus aspectos descritivos - que não

6 Que fazia desse jovem de 25 anos, sem ter estudado a economia política inglesa e a história política francesa, um defensor da democracia direta enquanto meio de supressão do Estado - o que depois, na maturidade teórica, é tido como fator condicionado à supressão das classes. Cf. Celso Frederico, Nas trilhas da emancipação - prefácio à MARX, Karl. Contribuição à crítica da filosofia do direito de Hegel: introdução. São Paulo: Expressão Popular, 2010 [1844], p. 18. 
são apenas econômicos, mas também culturais -, detém-se naquilo que designa enquanto uma classe-em-si: "a dominação do capital criou para esta massa uma situação comum, interesses comuns. Assim, pois, esta massa já é uma classe no que diz respeito ao capital, mas ainda não é uma classe para si” (MARX, 1981 [1847], p. 141). Estes indivíduos “encontram suas condições de vida preestabelecidas e têm, assim, sua posição na vida e seu desenvolvimento pessoal determinados pela classe; tornam-se subsumidos a ela" (MARX, 1993 [1846], p. 84).

Fica assim patente na análise marxiana que a existência de interesses comuns, caracterizados enquanto modos de vida diferenciais no todo social, não é tomado como fator suficiente da afirmação de uma classe. "Os indivíduos isolados apenas formam uma classe na medida em que têm que manter uma luta comum contra outra classe; no restante, eles mesmos defrontam-se uns com os outros na concorrência” (MARX, 1993 [1846], p. 84), com o detalhe de que para manter uma luta comum são necessários fatores que passam longe da simples disposição e vontade. Marx nos fala dos camponeses franceses sob o governo de Luís Bonaparte, incapazes de defenderem os seus interesses de classe em seu próprio nome: "Não conseguem representar-se a si mesmos, têm de ser representados". (MARX, 1975 [1852], p. 139).

É justamente nas pegadas da análise histórica de Marx em O 18 Brumário de Luís Bonaparte, que Gayatri Spivak (2010 [1985], p. 31-43) propõe pensarmos a descontinuidade fundamental entre os aspectos descritivos dos sujeitos/classes sociais e seus aspectos propriamente políticos, de subjetivação, agenciamento de interesses e transformação. A distância entre a representação como darstellen (ao lado dos interesses de classe determinados pelas condições objetivas de vida) e a representação como vertreten (ao lado da prática política, do desejo e do desvio) aponta para uma diferença substancial que também toca a relação e a descontinuidade irredutível entre os campos de referência das expressões do inglês consciousness e conscience - estar ciente, ter acordado, a capacidade de perceber, de um lado; e, por outro, ter senso moral, ter o senso de certo ou errado. Por mais que um dos termos venha a se apoiar no outro, a exemplo da assinatura como representação objetiva e a representação política do abaixo-assinado que a contém, é fundamental não diluir essa diferença. Segundo Spivak,

Marx não está trabalhando [em sua obra] para criar um sujeito indivisível, no qual o desejo e o interesse coincidem. A consciência de classe não opera com esse objetivo. Tanto na área econômica (capitalista) quanto na política (histórico-mundial), Marx é compelido a construir modelos de um sujeito dividido e deslocado cujas partes não são contínuas nem coerentes entre si. (SPIVAK, 2010 [1985], p. 34).

Uma tal consideração não faz absolutamente nenhum sentido na versão economicista e teleológica da existência das classes sociais, e, do outro lado, enriquece profundamente a versão de que as classes só existem a partir das lutas que travam, sendo que tais lutas nunca são homogêneas e lineares. Em relação ao problema da representação enquanto vertreten, agenciamento político, deve-se considerar que a classe não se torna "para si" por "revelação", nem simplesmente pela conscientização de suas condições de vida. Entendemos que o processo da consciência de classe dos trabalhadores, da "classe para si", define-se não simplesmente por saber as condições objetivas, mas pelo modo de insurgir-se contra tais condições, por afrontar a lógica policial que estabiliza e naturaliza seu lugar social, subjetivando-se contra o seu próprio ser de classe (contra o capital, a sua causa presente) 
e pela abolição de todas as classes, ou seja, da sociedade de classes - de modo análogo ao que foi a abolição da sociedade estamental pela revolução burguesa: a eliminação/superação da contradição fundante da ordem feudal.

Como é bem sabido no interior do campo marxista, o problema da consciência de classe dos trabalhadores, do agenciamento de seus interesses históricos e da sua representação tem sido o problema do partido revolucionário, em sentido amplo. Diante do que pode ser pensado como "embaraço" dos partidos comunistas em relação ao processo político de autoformação da classe trabalhadora, Michel Pêcheux fala da "metafísica marxista ortodoxa do realismo de classe", que

[...] subordina uma identidade estável (com fronteiras definidas) às ideologias e principalmente às ideologias políticas. Mas essa metafísica, que nunca arrisca nada, sempre significou um perigo para os movimentos populares e de trabalhadores: o papel nunca explicado do "populismo" foi tratado no âmbito dessa metafísica. [...] o mesmo marxismo ortodoxo se mostra incapaz hoje em dia de pensar, em seu próprio espaço do "socialismo existente", os efeitos de uma luta de classes, cujos atores lhe ficam invisíveis. Enquanto isso, se reproduzem as condições de um sistema de exploração original sem "capitalistas", principalmente por meio da divisão técnico-social-política do trabalho, garantida por um populismo de Estado [stalinismo], com efeitos retroativos imprevisíveis (PÊCHEUX, 2011 [1982], p. 116).

Considerando a classe trabalhadora um objeto - e um objeto de identidade estável - seus autoproclamados representantes nas lutas ideológicas e políticas puderam, na maior parte de sua atuação, deixar de trabalhar "no interior" da classe, de modo orgânico, sendo o recrutamento partidário pouco mais do que uma renovação de quadros, e se acomodaram numa representação "objetiva”, pela qual falam (de fora/acima) para a classe, o que, nos termos empregados por Mónica Zoppi-Fontana (1997, p. 128), representa "uma dominância dos processos metafóricos sobre os processos metonímicos da enunciação política". As palavras dos partidos comunistas nem coincidem com e nem traduzem as palavras do proletariado, elas as substituem. Tem-se assim um efeito oposto-complementar àquele produzido pelos intelectuais que, recusando a representação (e o comprometimento político), defendem que a classe fala por si, que ela é idêntica a si mesma - é uma das críticas de Gayatri Spivak (2010 [1985]) a Foucault e Deleuze. E tem-se assim também algo ainda mais grave, como nos indica João Bernardo (2009 [1991]): a recuperação das lutas mais intensas da classe trabalhadora por uma classe que, em verdade, de forma objetiva (demonstrável historicamente), é capitalista: a classe dos gestores. Classe essa que, objetivamente, conduziu as revoluções proletárias para uma "via prussiana de desenvolvimento capitalista" (PÊCHEUX, 2011 [1982]). O lema ou fórmula "socialismo = sovietes + eletrificação" muito provavelmente já padecia da armadilha ideológica-discursiva que trabalha assimetricamente os termos de uma conjunção, no caso o sinal "mais". Que tenha se dado o avanço da eletrificação e o recuo e enterro do regime dos conselhos operários autônomos é algo que o "cerco capitalista" só poderá justificar se admitirmos que ele foi, o tempo todo, um problema interno, e não gerado pelo imperialismo.

Sendo o proletariado, enquanto "classe para si", um processo histórico, uma tendência concreta (mas não inexorável) de dissolução de todas as classes, de decomposição da sociedade burguesa, de recuperação e agenciamento dos traços sociais de coletivismo e de igualitarismo em prol de novas relações sociais, torna-se impensável qualquer divisão que 
se queira estabelecer entre agentes e processos, vanguarda e classe, ou qualquer consciência que se queira conceber antes da prática real, apenas como interesses objetivos ou materiais a serem conhecidos e representados "de fora". A consciência que mais diretamente interessa ao marxismo são formas sociais determinadas e inscritas "no processo de vida social, política e intelectual” (MARX, 2008 [1959]), todo o complexo superestrutural e(m) suas lutas.

Para além de sua crítica à metafísica do realismo de classe, Michel Pêcheux (2011 [1982]) tem uma contribuição notável que nos auxilia a apreender as classes enquanto fatores históricos e contingentes, e não enquanto elementos funcional e estruturalmente tomados de antemão. Partindo daquilo que Gramsci chamou de "guerra de movimento", Pêcheux propõe pensarmos em termos de luta de deslocamento ideológica para descrever uma série de choques pertinentes à reprodução/transformação das relações de classes (PÊCHEUX, 2011 [1982], p. 114-115). Para o filósofo francês, por exemplo, o "socialismo existente" inscreveu sua relação na história do desenvolvimento do capitalismo através de uma sequência de incrustrações contraditórias no interior de seu próprio desenvolvimento geral. Sem supor ou projetar qualquer pureza traída, perdida ou desviada de uma "teoria marxista", trabalhando (ao invés disso) com autonomia o pensar crítico-marxista, Pêcheux chama a atenção para as lutas de deslocamento ideológicas que atravessam as formações sociais e mobilizam objetos paradoxais sob diversos nomes como Povo, direito, trabalho, gênero, vida, ciência, natureza, paz, liberdade, etc. São objetos que funcionam em relações de força móveis, que provocam confusão e cruzamentos, o que podemos acompanhar também na consideração de Slavoj Zizek quanto ao objetivismo "marxista" do governo soviético em relação às classes:

[...] em algum momento esse processo tem de ser interrompido por uma intervenção maciça e violenta da subjetividade: pertencer a uma classe nunca é um fato social puramente objetivo e é sempre o resultado da luta e do engajamento subjetivo. É interessante observar que o stalinismo se envolveu num impasse semelhante ao buscar determinações objetivas de pertencimento de classe - o impasse classificatório que ativistas políticos e ideólogos stalinistas enfrentaram em sua luta pela coletivização entre 1928 e 1933. Na tentativa de explicar o esforço para eliminar a resistência dos camponeses em termos marxistas "científicos", eles dividiram os camponeses em três categorias (classes): os camponeses pobres [...], aliados naturais dos operários; os camponeses médios autônomos, que oscilavam entre explorados e exploradores; e os camponeses ricos, os kulaks [...], o "inimigo de classe" explorador que, como tal, tinha de ser "liquidado". No entanto, na prática essa classificação se tornou cada vez mais indistinta e inoperante: naquela situação de pobreza generalizada, critérios claros não se aplicavam mais, e as duas primeiras categorias uniram-se muitas vezes aos kulaks para resistir à coletivização forçada. Criou-se então uma quarta categoria, a do subkulak, o camponês que, embora em relação à sua situação econômica fosse pobre demais para ser considerado um kulak propriamente dito, apresentava uma atitude "contrarrevolucionária". [... com o tempo] A arte de identificar kulaks, portanto, não era mais uma questão de análise social objetiva, mas de uma complexa "hermenêutica da suspeita", de identificar as "verdadeiras atitudes políticas" de alguém, ocultas por trás de declarações públicas enganosas, de modo que o Pravda teve de admitir que, "muitas vezes, nem os melhores ativistas conseguem perceber o kulak" (ZIZEK, 2012, p. 162-163).

A luta de classes é tida por Zizek como antagonismo que atravessa a realidade social em seus pontos de subjetivação. É então pertinente trazer Jacques Rancière novamente, que conceitua a subjetivação enquanto interrupção das capturas discursivas dominantes 
- o que Pêcheux conceituou enquanto desidentificação. Por estas vias de compreensão, subjetivar-se é reagir a um dano instaurando um litígio, o que Rancière sintetiza na imagem da instituição do partido/parcela dos sem-parcela:

Não há política simplesmente porque os pobres se opõem aos ricos. Melhor dizendo, é a política - ou seja, a interrupção dos simples efeitos da dominação dos ricos - que faz os pobres existirem enquanto entidade. A pretensão exorbitante do demos a ser o todo da comunidade não faz mais que realizar à sua maneira - a de um partido - a condição da política. A política existe quando a ordem natural da dominação é interrompida pela instituição de uma parcela dos sem-parcela. [...] Fora dessa instituição, não há política. Há apenas ordem da dominação ou desordem da revolta. (RANCIÈRE, 1996, p.26-27).

Na tese de doutorado (FONSECA, 2012) criticamos a afirmação de Rancière de que somente haveria política enquanto negação da dominação, de que "o partido dos ricos encarna nada mais que o antipolítico" (RANCIÈRE, 1996, p. 29). Acompanhamos o que diz Michel Pêcheux (1997 [1975], p. 203) de que a burguesia efetivamente faz política, mas a faz de modo dissimulado, sob as formas da ficção e do jogo eleitoral-parlamentar (fingindo que tudo pode acontecer) ou da denegação de viés pragmático e jurídico (fingindo que apenas aquilo e nada mais pode acontecer).

As ideologias contrahegemônicas nascem no lugar mesmo da dominação ideológica na forma de múltiplas falhas e resistências. Investigando a Conjuração Baiana de 1798, recuperamos o trabalho dos sujeitos históricos desejantes de uma revolução francesa nos trópicos, a sua constituição enquanto instância enunciativa capaz de sustentar posições interrompendo os simples efeitos de uma dominação, produzindo o sentido do interior do sem-sentido, trabalhando para que o impossível se tornasse inevitável: uma aliança entre escravizados e escravizadores para derrubar a monarquia e instaurar uma república igualitária e independente na Bahia, com o auxílio de Napoleão Bonaparte e suas tropas. Foram derrotados. Mas se simplesmente olhamos para esse fato e identificamos que perderam por querer o impossível, de algum modo nos somamos à narrativa dos vencedores...

Não é o caso de conceber uma prática social qualquer que já não faça sentido e não pressuponha sujeitos, como num "estágio social" livre de assujeitamento histórico, das coerções herdadas que nos colocam em determinados lugares antes mesmo que a gente abra a boca e depois mesmo que a gente fale contra elas. Esse "campo do sem-sentido" e da "multiplicidade de fraturas" e "traços latentes" deve ser considerado como aquilo que está sendo efetivamente jogado na história, as muitas brechas e vãos que fazem com que a história e os sentidos se realizem à distância de qualquer inexorabilidade socioeconômica (em última instância) e de uma exterioridade qualquer dos sujeitos (mesmo os do partido portador da teoria revolucionária), o que no início do projeto teórico de Pêcheux implicava o primado da teoria sobre a prática (PÊCHEUX, 1997 [1978], p. 299).

\section{Considerações finais}

Para os que seguimos trabalhando o legado marxista de Michel Pêcheux, não se trata exatamente de considerar que "Um outro mundo é possível", mas sim que Um outro mundo é o impossível... o impossível na ordem dominante atual, o impossível no capitalismo. "As revoluções são impossíveis, até que se tornem inevitáveis", disse Trotsky, "tudo o que é sólido desmancha no ar", Marx e Engels. Esse batimento real no coração da ordem é o que 
de fato dá trabalho aos conservadores e reacionários. É propriamente aí que está a políti$\mathrm{ca}$, a política real e contingente, aquela que pressiona para que algo efetivamente mude e para que esse algo permaneça como está. O real da política não é que algumas coisas - as prioridades, por exemplo - mudem e outras permaneçam, mas que haja constantemente essa pressão e que ela seja inevitável.

Uma abordagem materialista dos processos considerados superestruturais, que desfaça em seu interior a cegueira, a esterilização e o apartamento das relações de produção e das forças produtivas, certamente tem a ganhar com as problemáticas propostas por Rancière $\mathrm{e}$ Pêcheux, do desentendimento como a lógica da política e da política como funcionamento (do) significante. Temos aí elementos importantes e estratégicos ao guia de estudos e intervenção do materialismo histórico no que diz respeito, em especial, aos processos que conformam estes sujeitos peculiares, as classes, a partir do desentendimento e da desidentificação com as suas coordenadas prévias, com a implosão de determinados preconstruídos e a abertura de novas possibilidades de (se) deslocar, subtrair, subjetivar e fazer sentido.

\section{Referências}

ALTHUSSER, Louis. Ideologia e Aparelhos Ideológicos do Estado. Porto Editorial Presença; São Paulo: Martins Fontes, 1974 [1970]. Tradução de Joaquim José de Moura Ramos.

BERNARDO, João. [1991] Economia dos Conflitos Sociais. 2a edição. São Paulo: Expressão Popular, 2009.

BRITO, Felipe Mello da Silva. Da "estadolatria" à negatividade política: (re)pensando alguns tópicos sobre a crítica imanente em Karl Marx. Programa de Pós-Graduação em Sociologia e Direito/Universidade Federal Fluminense (dissertação de mestrado), 2005. CHIBBER, Vivek. O que vive e o que está morto na teoria marxista da história. Tradução de Leonardo Schiocchet. Crítica Marxista, São Paulo, n. 35, p. 9-40, 2012. ENGELS, Friedrich. Carta a Conrad Schmidt, 5 de agosto de 1890. http://www.scientific-socialism.de/FundamentosCartasMarxEngels050890.htm . Acessado em 02/02/2012. . Carta a Werner Sombart, 11 de março de 1895. http://www.marxists.org/portugues/marx/1895/03/11.htm. Acessado em 30/01/2013.

FONSECA, Rodrigo Oliveira. A interdição discursiva: o caso da Conjuração Baiana e outros limites à participação popular na história brasileira. Programa de Pós-Graduação em Letras/Universidade Federal do Rio Grande do Sul (tese de doutorado), 2012. FREDERICO, Celso. Nas trilhas da emancipação - prefácio à MARX, Karl. Contribuição à crítica da filosofia do direito de Hegel: introdução. São Paulo: Expressão Popular, 2010 [1844].

GRAMSCI, Antonio. [1929-35] Cadernos do Cárcere. (Volumes III: Maquiavel - notas sobre o Estado e a política) $2^{\mathrm{a}}$ ed. Rio de Janeiro: Civilização Brasileira, 2002. Tradução de Luís S. Henriques, Marco A. Nogueira e Carlos N. Coutinho.

IASI, Mauro Luís. O dilema de Hamlet. O ser e o não ser da consciência. São Paulo: Viramundo, 2002.

INDURSKY, Freda. A fala dos quartéis e as outras vozes. Campinas: Ed. da Unicamp, 1997. MALDIDIER, Denise. [1990] A inquietação do discurso - (Re) ler Michel Pêcheux hoje. Campinas, SP: Pontes, 2003. Tradução de Eni Orlandi.

MARX, Karl. [1844] Glosas críticas marginais ao artigo "O rei da Prússia e a reforma 


\section{Conexão Letras}

social". De um prussiano. In: Novos Temas: Revista de Estudos Sociais e Ciências Humanas Salvador: Quarteto; São Paulo: Instituto Caio Prado Jr., v. 02, n. 02, set. 2010-mar. 2011, p. 37-50.

. [1844] Manuscritos Económico-Filosóficos.. Lisboa: Edições 70, 1993. Tradução de Artur Mourão

. [1847] A Miséria da Filosofia. Moscou: Editorial Progresso, 1981.

. [1852] O 18 Brumário de Luís Bonaparte. Lisboa: Editora Ventos do Leste, 1975.

[1857] Grundrisse.. São Paulo: Boitempo, 2011. Tradução Mario Duayer e Né-

lio Schneider

[1859]. Contribuição à crítica da economia política. $2^{\mathrm{a}}$ edição. São Paulo:

Editora Expressão Popular: 2008. Tradução de Florestan Fernandes.

[1867, 1885, 1894] O Capital - edição resumida dos três volumes por Julian

Borchardt (1931). $7^{\mathrm{a}}$ edição. Rio de Janeiro: Ed. Guanabara, 1982. Tradução de Ronaldo Alves Smidth.

MARX, Karl \& ENGELS, Friedrich. [1846] A Ideologia Alemã (Feuerbach).. São Paulo: Hucitec, 1993. Tradução de José Carlos Bruni e Marco Aurélio Nogueira

. [1848] O Manifesto Comunista. $5^{\text {a }}$ edição revista. Rio de Janeiro: Paz e Terra,

1998. Tradução de $\mathrm{M}^{\mathrm{a}}$ Lucia Como.

MONTENEGRO, Darlan. A separação entre o econômico e o político e a questão da democracia no pensamento de Ellen M. Wood. Crítica Marxista, São Paulo, n. 34, p. 111-124, 2012.

NETTO, José Paulo. O que é stalinismo. São Paulo: Brasiliense, 1984.

PÊCHEUX, Michel. [1975]. Semântica e discurso: uma crítica à afirmação do óbvio. $3^{\text {a }}$ edição. Campinas, SP: Editora da Unicamp, 1997. Tradução de Eni Orlandi [et al.].

. [1978] Só há causa daquilo que falha ou o inverno político francês: início de uma retificação. Tradução de Eni Orlandi [et al.]. In: PÊCHEUX, Semântica e Discurso: uma crítica à afirmação do óbvio. Campinas, SP: Ed. da Unicamp, 1997, p. 293-304.

. [1982] Delimitações, inversões, deslocamentos. Tradução de José Horta Nunes. Cadernos de Estudos Lingüísticos, Campinas, (19): 7-24, jul.-dez./1990.

. [1982] Ideologia - aprisionamento ou campo paradoxal? Tradução de Carmen Zink. In: PÊCHEUX, M. Análise de Discurso - Michel Pêcheux. Textos selecionados por Eni Orlandi. 2a edição. Campinas, SP: Pontes, 2011, p. 107-119.

. [1983]. O discurso: estrutura ou acontecimento.. $2^{\mathrm{a}}$ edição. Campinas, SP: Pontes, 1997. Tradução de Eni Orlandi

RANCIÈRE, Jacques. O desentendimento: política e filosofia. São Paulo: Editora 34, 1996. Tradução de Ângela Leite Lopes.

SAMPAIO, Benedito Arthur \& FREDERICO, Celso. Dialética e materialismo: Marx entre Hegel e Feuerbach. Rio de Janeiro: Editora UFRJ, 2006.

SHAW, William H.. [1983] verbete Materialismo Histórico no Dicionário do Pensamento Marxista, editado por Tom Bottomore. Tradução de Waltensir Dutra. Rio de Janeiro: Zahar, 1988.

SPIVAK, Gayatri Chakravorty. [1985] Pode o subalterno falar? Tradução de Sandra R. G. Almeida, Marcos P. Feitosa e André P. Feitosa. Belo Horizonte: UFMG, 2010. (2010, ZIZEK, Slavoj. [1994] Como Marx inventou o sintoma? In: ZIZEK (org.) Um mapa da ideologia. Tradução de Vera Ribeiro. Rio de Janeiro: Contraponto, 1996, p. 297-331.

Vivendo no fim dos tempos.. São Paulo: Boitempo, 2012.

ZOPPI-FONTANA, Mónica. Cidadãos Modernos: discurso e representação política. Campinas, SP: Ed. UNICAMP, 1997. Tradução de Maria Beatriz de Medina 